\title{
Vincenzo Vincenzi, “Geometer and Engineer to Cardinal Borja"*
}

\author{
Mercedes Gómez-Ferrer \\ Universitat de València \\ mercedes.gomez-ferrer@uv.es \\ Yolanda Gil \\ Universitat de València \\ yolanda.gil@uv.es
}

\begin{abstract}
This paper analyses the figure of Vincenzo Vincenzi on the basis of documents that place him in Valencia in 1635 as engineer and geometer to Cardinal Gaspar de Borja y Velasco. Vincenzi, who was born in the Urbino region, worked as a hydraulic engineer at the Villa d'Este in Tivoli. In Rome he made his name as the inventor of the wind gun and the mobile fountain, inventions that were disseminated through the works of Benedetto Castelli and, above all, those of Giovanni Faber who also served as an intermediary, recommending Vincenzi's services to cardinals such as Emmanuele Pio di Savoia and taking it upon himself to find buyers for the wind gun. Vincenzi worked for the Bentivoglios on the bonifica del Gualtieri, and the Venetian Republic expressed its desire to purchase a number of his inventions, after which he travelled to Spain at the request of Borja in order to drain a salt marsh on the cardinal's estates.
\end{abstract}

\section{Keywords}

hydraulic engineer - Cardinal Gaspar de Borja y Velasco - Vincenzo Vincenzi

* This research work has been financed by the Ministerio de Economía y Competitividad, Spain, Research Project, HAR 2014-54751-P, ECOVAME; Cultural, artistic and architectonic echoes between Valencia and the Mediterranean in Modern times. 
"Who was Vincenzo Vincenti of Urbin?" This is one of the questions that have remained unanswered in the re-issue of the complete works of Robert Boyle $(1627-1691){ }^{1}$ At the height of the dispute between Boyle and Hobbes on matters relating to perfecting the air pump and the possibility of creating a vacuum, in 1662 the former wrote An Examen of Mr. T. Hobbes His Dialogus Physicus de Natura Aeris, ${ }^{2}$ where he mentions Vincentio Vincenti Urbinate as the inventor of the fontibus vitreis or glass fountains, in which water was thrown up by compressed air. ${ }^{3}$ Since the publication in 1983 of documented information pertaining to a hydraulic study conducted on the banks of the River Júcar (Valencia, Spain) in 1635 by the reputed Jesuit Pablo Albiniano de Raxas and the enigmatic "Vicentius Vincensi de nacion romano, vecino de Gandía, geometra $e$ ingeniero del cardinal Borja [geometer and engineer to Cardinal Borja, of Roman extraction, residing in Gandía]," of whom nothing more was known and who then faded into oblivion, a similar, apparently unrelated question also remained open. Could this be a mere coincidence? Or could they be the same person in two such different contexts? On the basis of these premises, we will endeavour to solve the mystery surrounding the identity of the 17thcentury Italian man of science, Vincenzo Vincenzi, ${ }^{4}$ originally from Orciano da Pesaro, in the vicinity of Urbino, resident of Rome, admired in his own time and acknowledged as the inventor of the wind gun and the portable fountain, a hydrologist in the service of the Estes, the Bentivoglios and Cardinal Borja, and connected to some of the most outstanding mathematicians and scientists of his time.

1 www.bbk.ac.uk/boyle/worksqueries.html (accessed 8 April 2016) This webpage lists the questions that still remained unanswered before the publication of the new 14-volume edition prepared by Michael Hunter and Edward B. Davies, The Works of Robert Boyle (London: Pickering and Chatto, 1999-2000).

2 In 1661 Thomas Hobbes published his Dialogue Physicus de Natura Aeris, which was contested by Boyle the following year in his An Examen of Mr. T. Hobbes His Dialogus Physicus de Natura Aeris (London: ed. Thomas Robinson, 1662), p. 64. "In the 24 page Mr Hobbs has that passage I formerly recited touching the Glass Fountains, out of which water is thrown up by compressed air. But though I as well as others have made use of such Fountains, invented by Vincenzo Vincenti of Urbin [...]."

3 In this regard, see Steven Shapin and Simon Schaffer, Leviathan and the Air Pump (Princeton: Princeton University Press, 1989).

4 Hereinafter, we will refer to him by this name, although its spelling can differ depending on the source. 


\section{The Inspection of the Júcar of 1635}

Located to the south of Valencia in what is now the region of the Ribera, since the Middle Ages the River Júcar has seen renowned master builders, surveyors, engineers and mathematicians responding to the call of the authorities of riverine communities or noble landowners to settle water-related issues. Matters pertaining to irrigation, floods (which were particularly serious in 1571 and 1581), attempts at making the river navigable, and jurisdictional lawsuits had convened experts throughout the ages. ${ }^{5}$ One such on-site inspection, ${ }^{6}$ taking place from 16 to 24 April 1635, was conducted by three experts, on this occasion at the joint request of the Viceroy of Valencia, Pedro Fajardo Requesens y Zúniga (1602-1647), 5th Marquis of los Vélez, and of the municipalities of the Ribera del Júcar, so as to report on the causes behind the flooding of the river and to suggest possible solutions to avoid further damage. This inspection was conducted by Father Albiniano de Raxas, ${ }^{7}$ a well-known Jesuit scholar, antiquarian, map-maker and architect; Gaspar Merino, ${ }^{8}$ a local master builder from the city of Valencia, who also concerned himself with issues related to hydraulics; and Vicentius Vincensi, an obscure Italian of whom little more was known than what he himself had asserted in a document drafted in Valencia on 4 May 1635, introducing himself as a Roman geometer and engineer to Cardinal Gaspar de Borja, and a resident of Gandía.

5 Salvador Albiñana and Telesforo Hernández, "Notas sobre técnica y proyectismo en la Albufera y el Júcar en la Edad Moderna," Estudis, 1983, 10:55-90.

6 Municipal Archive of Alzira, (AMA), Río Júcar, carpeta 9, without foliation.

7 Pablo Albiniano de Raxas, (1583-1667). Jesuit, geographer, antiquarian and architect, he is a truly remarkable figure in the Spanish architectural culture of the first half of the 17 th century, on whom a case study has yet to be conducted. Further discussion of this figure is far beyond the limitations and purpose of this work.

8 AмA, Río Júcar, carpeta 11, mentions Gaspar Merino, "obrer de vila de Valencia [a worker of the city of Valencia]," who hitherto had not appeared in the references. Merino was a master builder and hydraulic engineer who had been working in the Albufera de Valencia since 1607 , building a canal with the Italian engineer Cristóbal Antonelli, Archivo Corona de Aragón, ACA, Mapas y Planos 3/1 and 3/2 showing the design of these works, and legajo 653, document 35/2. In 1613 he was to be found building the Chapel of Communion in the church belonging to the Convent of Carmen in Valencia, Carmen García, Arquitectura del convento del Carmen (Valencia: Colegio de Arquitectos, 1988), p. 27, and in 1624 he is known to have been involved in the construction of the weir on the River Mijares (Castellón), Ferrán Olucha, Dos siglos de actividad artística en la villa de Castellón, 1500-1700 (Castellón: Diputación, 1987), p. 61 . 
These documents conserved in the archives of the town of Alzira, one of the communities requesting the inspection, were brought to light by Mateu ${ }^{9}$ who commented briefly on the reports of Raxas and Vincenzi, noting that it would be interesting to conduct a more in-depth study due to the quality of the expert opinions delivered. The rough draft or sketch by Vincenzi (Fig. 1), featuring the measurements that he took in situ, was published by Faus Prieto ${ }^{10}$ in 1996. Neither the first articles appearing in the 1980s, nor those published in the $1990 \mathrm{~s}$ or in more recent years ${ }^{11}$ have provided further clues as to the identity of this engineer, although all the aforementioned authors concurred in underscoring the importance of the fresh information provided by these reports.

They included a study of the Júcar from inland village of Antella to the river mouth at Cullera, along with an analysis of potential flood causes. A mention was made of the problems created by the azudes [the Arabic term for weir], the majority of which, it was suggested, should be eliminated; an analysis of the river course was conducted, indicating that it should be widened and that it would be well advised to construct new intakes to supply the irrigation canals; and the blame was placed to a great extent on the silting of the river and its excessive number of meanders. In his sketch Vincenzi included a topographic profile with a slope gradient between the two municipalities of around 16 metres (70 handspans) and proposed opening two canals, one for Cullera and Sueca, and another for Corbera and Llaurí, calculating a lower expenditure of time and money compared with other solutions such as dredging the riverbed. Neither expert baulked at contradicting previous inspections, even one as important as that carried out by the professor of mathematics and cosmography Pedro Esquivel, chaplain to King Philip II, who visited the Ribera in 1562 and concluded that the weirs were not the cause of the flooding, although he proposed opening more canals in association with these weirs. ${ }^{12}$

The thorough examination conducted by the three experts in 1635 finally led to a concord being signed on 8 May of that same year between Alzira ${ }^{13}$ and

9 Joan F. Mateu, "La ciencia i la técnica davant les revingudes del Xùquer (1635-1905), Notes preliminars," Cuadernos de Geografía, 1983, 32-33:243-264.

10 Alfredo Faus, "Cartografía e Hidrometría en el siglo xviıI valenciano. El ejemplo de la Acequia Real del Júcar," Cuadernos de Geografía, 1996, 59:119-140.

11 Tomás Peris, "Las inundaciones del Xúquer (siglos XV-XIX). Un exponente relevante de la cuestión hidráulica en tierras valencianas," Revista de Historia Moderna, 2005, 23:75-108.

12 AMA, Río Júcar, signatura: 4.

13 Andrés Piles, Historia de Cullera (Sueca: printed by Ricardo Benedito, 1893), pp. 520524 . 


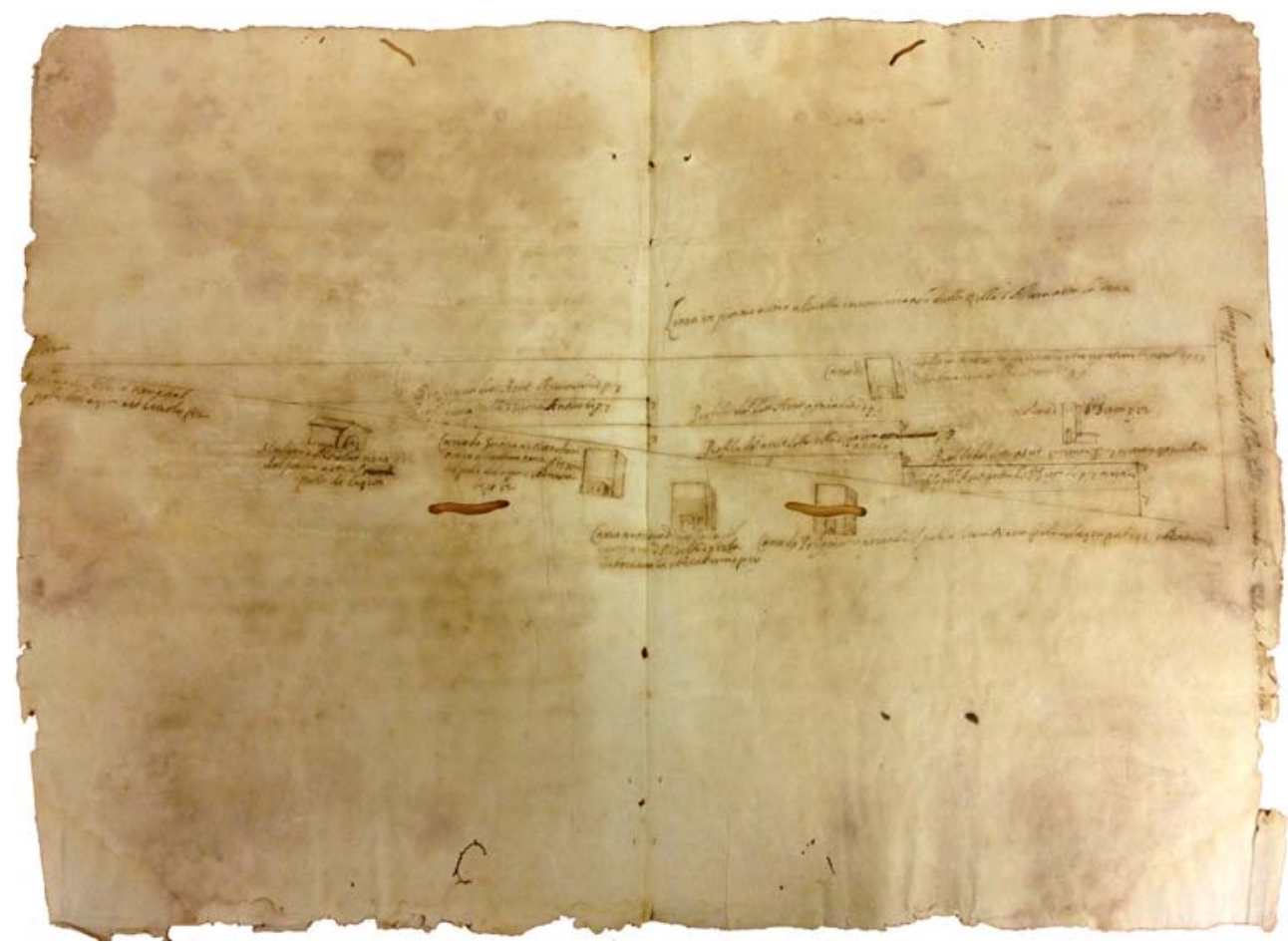

FIGURE 1 Sketch drawn by Vincenzo Vincenzi of the River Jucar between Alzira and Cullera, (Valencia, Spain), 1635

ARCHIVO MUNICIPAL DE ALZIRA, RÍO JÚCAR, CARPETA 11

other villages aimed at avoiding the disastrous effects of inundations, which remained in force until the flood of 1791 . On the strength of this incident, which might have been just another interesting case of foreign engineers addressing hydraulic issues in Spain, we will now try to shed some light on the identity of the engineer Vincenzo Vincenzi, of whom hitherto nothing was known.

\section{Vincenzo Vincenzi, urbinate}

Although in the documents found in Valencia, Vincenzo Vincenzi is described as de nacion romano, Rome being the city of residence of Cardinal Borja and where Vincenzi was living before he travelled to Spain, his Roman contemporaries referred to him as urbinate, i.e. from Urbino. In the field of mathematics and engineering, the allusion to Urbino implies much more than a mere geographical designation, since this affinity also implied exposure to a cultural tradition. In his comments on the illustrious men of Urbino, Carlo Grossi 
includes Vincenzo Vincenzi among those who followed in the wake of Federico Commandino, and describes him as the nephew of Muzio Oddi. ${ }^{14}$ Grossi had probably got the wrong end of the stick here; the mathematician Mutio or Muzio Oddi was related to the Vincenzi family of Urbino, one of whose number was a nephew called Vincenzo Vincenzi, but the biography of this Vincenzi, a priest who was born in 1605 and died in 1635, does not seem to be consistent with that of our protagonist. Based on his own words, we know that Vincenzo Vincenzi came from the region of Urbino, although not from the city itself, but from Orciano di Pesaro. ${ }^{15}$

This does not prevent us from understanding Vincenzi's training solely in the context of the Duchy of Urbino, where the mathematicians Federico Commandino (1509-1575), Guidobaldo del Monte $\left(1545^{-1607}\right){ }^{16}$ Simone Barocci $\left(1535^{-1612}\right)$ and Oddi himself $\left(15^{6} 9^{-1639}\right)^{17}$ had worked. It was in Urbino that the so-called "renaissance of mathematics" came about, fostered by Commandino's translations of classic works. The school of Urbino not only recuperated the mathematical humanism of the works of Euclid, Archimedes and Apollonius, but also a technical humanism deriving from the translation of the works of Hero of Alexandria. ${ }^{18}$ The Pneumatica was translated into Latin

14 Carlo Grossi, Degli uomini illustri di Urbino: Comentario (Urbino:Vincenzo Guerrini, 1820), p. 72.

15 In 1604 Francesco Maria Vincenzi married Lavinia Oddi, the sister of the mathematician. The brothers of Francesco María included Lodovico, rector of the Church of St. Bartholomew in Urbino, theologian and mathematician, and Guidobaldo, president of the Borromeo's College in Pavia and confessor to Carlo Borromeo, who had taken up residence in Milan. We would like to thank Federico Marcucci of the Biblioteca dell'Università degli Studi di Urbino for his assistance and information on the Vincenzi collection. In one of the letters in this collection (Busta 36, Fascicolo v, lettera h, carta 659), the ecclesiastic Vincenzo Vincenzi residing in Rome alludes to another Vincenzo Vincenzi of Urbin residing in the city at the same time (24 October 1629 ), which led to some confusion in the receipt of postal mail. This other Vincenzi, who was not directly related to Muzio Oddi, must be the one that interests us.

16 On this issue, see Antonio Becchi, Domenico Bertoloni Meli and Enrico Gamba, Guidobaldo del Monte (1545-1607). Theory and Practice of the Mathematical Disciplines from Urbino to Europe (Berlin: Max Planck Research Library for the History and Development of Knowledge, 2013).

17 On Oddi and the mathematical tradition of Urbino, see Alexander Marr, Between Raphael and Galileo. Mutio Oddi and the Mathematical Culture of Late Renaissance Italy (Chicago and London: University of Chicago Press, 2011).

18 Giovanni, Ferraro, Bernardino Baldi e il recupero del pensiero tecnico-scientifico dell'antichità (Alessandria: Edizioni dell'Orso, 2008). 
by Commandino in 1575 in collaboration with Bernardino Baldi, ${ }^{19}$ who in 1589 published Automati, ${ }^{20}$ in which he differentiated between automata that functioned with weights or counterweights and the "spiritali" propelled by air pressure, and in 1592 Alessandro Giorgi translated the Spiritali ${ }^{21}$ into Italian. It was also in Urbino that Simone Barocci set up the Officina di strumenti matematici, from which Galileo himself commissioned a compass. On the death of Barocci in 1608 , this workshop dedicated to the making of mathematical instruments was then run by Lorenzo Vagnarelli, who probably had some connection with Vincenzi. ${ }^{22}$ At that time, not only did the potential applications of these instruments excite the interest of specialists, but the objects themselves became status symbols. It was thanks to the craft learnt in this workshop that watches and automata could be made, drawing inspiration from the writings of Hero of Alexandria.

\section{Vincenzo Vincenzi, fontanaro of the Villa d'Este}

While Vincenzi's training can largely be explained in the context of the Duchy of Urbino, it was only in Rome that he was able to find a receptive audience with regard to his research and it was primarily in this city that he plied his trade as a fontanaro - a hydraulic engineer - in the service of different cardinals.

The first news that we have of the fontanaro Vincenzo Vincenzi places him in 1619 at the Villa d'Este in Tivoli. During this time Vincenzi must have worked in the service of Cardinal Alessandro d'Este, who from 1605 to 1624 was Governor of Tivoli, where he implemented a broad programme of reconstruction projects. ${ }^{23}$ When Vincenzi arrived at the villa in 1619, these projects had largely been completed, but even so he put forward a programme of improvements

19 Heronis Alexandrini Spiritalium Liber, a Federico Commandino Urbinate, Ex Graeco, Nuper in Latinum Conversus (Urbino: Frisolino Domenico, 1575).

20 Erone Alessandrino, De gli automati overo machine se moventi, Libri due, tradotti dal greco da Bernardino Baldi. Abbate di Guastalla (Venezia: Girolamo Porro, 1589).

21 Spiritali di Herone Alessandrino Ridotti in lingua vulgare da Alessandro Giorgi da Urbino (Urbino: Bartholomeo e Simoni Ragusi fratelli, 1592).

22 An inventory of the library of the Albani family in 1700 refers to a manuscript bearing the title "Memorie di Lorenzo Vagnarelli Matematico meccanico, di Vincenzo Vincenzi locato come inventore dell'archibugio a vento," Cecil H. Clough, "Sources for the History of the Duchy of Urbino in Pope Clement XI's Library: A Miscellany in Seventeen Volumes," Manuscripta, 1970, 14:151-165. Cecil H. Clough, The Duchy of Urbino in the Renaissance (London: Variorum reprints, 1981), p. 169.

23 At around this time the cardinal was residing in Modena and his secretary at the time, 
with which we are familiar thanks to statements he made after the cardinal's death in 1624, when Cesare d'Este, Duke of Modena, took possession of the villa. ${ }^{24}$ During this time the fontanaro must have concerned himself mainly with restoration work on the old fountains, cleaning the aqueduct, recuperating the organ, and rebuilding the Fontana della Civetta.

In addition to this restoration work, Vincenzi proposed a series of "inventions." Whether these were put into practice it is hard to know, but a perusal of his text certainly provides indications of his skills and the environment in which he worked. The villa's chief appeal was the surprise effect of the play of water in its gardens. ${ }^{25}$ Visitors approaching the fountains had to be "duped" and to this end it was necessary to replace the cork plugs, which were a fair distance away, with a casino discretely located somewhat closer by, where the fontanaro could operate the devices quickly without being seen and just at the right moment.

Vincenzi's inventions basically involved the introduction of automata in the gardens. At the main entrance he proposed to place two statues holding arquebuses, which could move and spray visitors with water as they arrived along the path leading from the entrance to the scalinata dei draghi, as well as a water pergola beneath which they could walk without getting wet, whereas alternatively when they reached La Roma and the famous Fontana della Rometta it was suggested that its waterworks be improved so that it could also douse visitors depending on who they were. Vincenzi proposed important innovations; the villa had many fountains, but lacked sources of artificial winds, so he offered to create them in the Stanza delli Specchi and outside the Fontanone, coming up with the idea of building moving statues engaged in different actions. Vincenzi's practical sense is demonstrated by his proposal that the statues be made of wood in order to cut costs and make it easier for them to be assembled and dismantled, to facilitate their mechanical movements, and to allow them to be stored during the winter months when the fountains were turned off.

the scholar Antonio Querengo, oversaw the works, which were completed in 1618. The following year his secretary was Agostino Mascardi, who later became acquainted with Cardinal Borja.

24 Document reproduced in David R. Coffin, The Villa d'Este at Tivoli (Princeton: Princeton University Press, 1960), pp. 166-17o. Regarding this restoration work, see Patrizio Barbieri, “Organi e automi musicali idraulici di Villa d'Este a Tivoli," L'Organo. Rivista di cultura organaria e organistica, 1986, 24:3-61.

25 Letter dated 17 October 1620 and addressed to Cesare d'Este, reproduced in Biblioteca Enciclopedica Italiana, Vol. xxxıv, Opere di Gabriello Chiabrera e Fulvio Testi (Milano: Nicolo Betoni, 1834), p. 512. 
This type of artefact must have been greatly to the cardinal's liking, particularly as he had travelled widely in Europe, visiting the courts of France, Spain and Prague (where Rudolf II had shown him an organ that played without the need for an organist ${ }^{26}$ ) and spending much time in Venice. He was not only on friendly terms with men of letters and humanists, but also had a taste for the New Science. Alessandro d'Este, who had corresponded with Galileo since 1599 and was kept posted on developments in the Copernican controversy in Rome ${ }^{27}$ received a copy of Galileo's pamphlet "Discourse on the Comets" and wrote to him in 1619 requesting a replacement after having $\operatorname{lost}^{28}$ the first. He also asked the astronomer to draw up his birth chart. ${ }^{29}$ When the cardinal died in 1624, Galileo took it upon himself to break the news to Federico Cesi, telling him that he had visited the prelate just ten days before and engaged "in lungo raggionamento et allegro, passeggiando in camera sua [in long and cheerful discussion, walking back and forth in his room]."30

The projects developed by Vincenzi for the Villa d'Este involved hydraulic engineering based on a careful study of the texts of antiquity, ${ }^{31}$ following in the footsteps of Pirro Ligorio and even more importantly of Giovanni Battista Aleotti, ${ }^{32}$ an engineer with close links to the Este family. In those years scholars

26 H. Colin Slim, “Tintoretto's 'Music-making women' at Dresden," Imago Musicae, 1987, 4:4576 .

27 Between 1615 and 1616, while Galileo was in Rome defending the theories of Copernicus, the cardinal's secretary kept the prelate duly informed about all new developments. Apparently Galileo claimed that he wanted to travel to Modena to explain his stance to the cardinal in person, Maurice A. Finochiaro, "Fair-mindedness versus Sophistry in the Galileo Affair: Two Controversies for the Price of One," in Controversies Within the Scientific Revolution, edited by Marcelo Dascal and Victor D. Boantza (Amsterdam/Philadelphia: John Benjamins Publishing Company, 2011), pp. 53-76.

28 Lettere inedite di Galileo Galilei raccolte dal dott. Arturo Wolynski (Firenze: Tipografia dell'Associazione, 1872), p. 52. Letter from Cardinal Alessandro d'Este to G. Galileo, Modena, 16 July 1619 .

29 Mario Biagioli, Galileo cortesano. La práctica de la ciencia en la cultura del absolutismo (Buenos Aires: Katz, 2008), p. 66.

30 Eugenio Alberi and Celestino Bianchi, Le opere di Galileo Galilei, Vol. vi (Firenze: Società editrice fiorentina, 1847), p. 294.

31 Pamela O. Long, "Hydraulic Engineering and the Study of Antiquity: Rome, 1557-70," Renaissance Quarterly, 2008, 61:1098-1131. Alexander Gustav Keller, "Pneumatics, Automata and the Vacuum in the Work of Giambattista Aleotti," The British Journal of the History of Science, 1967, 3:338-347.

32 Alessandra Fioca (ed.), Giambattista Aleotti e gli ingegneri del rinascimento (Firenze: Olschki, Biblioteca di Nuncius, Vol. 31, 1998). 
such as Aleotti, Salomon de Caus and Gaspar Schott would publish a good number of texts relating to water-powered automata and sound-producing artefacts devised for use in gardens. Giovanni Battista Aleotti (1546-1636), the engineer who was placed in charge of the drainage of the territory surrounding Ferrara, published in 1589 Gli artificiosi et curiosi moti spirituali di Herone Alessandrino, dedicated to Alfonso II d'Este. This work, which discussed automata, gardens, and the way to obtain different birds sounds, was quite well received and was reprinted many times.

In the same period that Vincenzi was working at Tivoli, Salomon de Caus published in Paris Les Forces mouvantes (1624), ${ }^{33}$ which he dedicated to King Louis XIII, and some decades later, in 1657, Gaspar Schott would publish Mechanica hydraulico-pneumatica in which he mentions many examples of organs and sound machines, especially from the courts of northern Europe. ${ }^{34}$ All of these texts shared a focus on the world of gardens and Hero's texts, and their common origin can be traced to the translation of the Pneumatica of Heron that Bernardo Buontalenti, engineer to the Grand Duke of Tuscany, commissioned in 1582 from Oreste Vannoccio Biringuccio while the Pratolino Gardens were being built. ${ }^{35}$

\section{Vincenzo Vincenzi, Inventor of the Wind Gun}

The year in which Cardinal Alessandro d'Este died (1624) was also the inaugural year of the pontificate of Pope Urban VIII in Rome, a time marked by the clear rift between the Papacy and the Spanish Crown. With the support of Venice, French troops had occupied the Valtellina, and the number of foreigners in Rome was dwindling quickly since there was fear of imminent

33 Salomon de Caus, Les Raisons des forces mouvantes avec diverses machines tant utilles que plaisantes ausquelles sont adjoints plusieurs desseigns des grotes et fontaines (Frankfurt: Jan Norton, 1615). About this, Luke Morgan, Nature as Model: Salomon de Caus and Early Seventeenth-Century Landscape Design (Pennsylvania: University of Pennsylvania Press, 2006).

34 Gaspar Schott, Mecanica Hydraulico-pneumatica (Wurzburg: Schönwetter and Hertz, 1657), Alfredo Aracil, "Un poco de historia: diseños sonoros en los jardines del Renacimiento y el Barroco," in IEncuentro Iberoamericano sobre Paisajes Sonoros (Madrid: Instituto Cervantes, 2007).

35 Matteo Valleriani, "The Transformationand Reconstruction of Hero of Alexandria's Pneumatics in the Garden of Pratolino," in Pratolino, un mito alle porte di Firenze, edited by Luigi Ulivieri and Simonetta Merendoni (Venezia: Marsilio, 2009), pp. 155-181. 
war, compounded by Cardinal Borja's threat to allow Spanish troops to enter the city. ${ }^{36}$

Nevertheless the cultural life during these years remained intense in Rome, with the courts of the cardinals, the religious orders, ambassadors and aristocrats organizing academic meetings and assemblies. At these salons participants listened to discussions of topical controversies and original interpretations of new developments that reflected the intellectual freedom enjoyed by these virtuosi. The majority of these salons were of an ephemeral nature, as was the loyalty to them of the many scholars, literati and scientists caught up in the dynamics of patronage. ${ }^{37}$

The ascension to the papacy of Maffeo Barberini, who took the name of Urban VIII, placed the focus on what was to become one of the most important Roman academies, the Accademia dei Lincei founded by Federico Cesi, of which Cardinal Barberini and his secretary ${ }^{38}$ were both members. With Alessandro d'Este now dead and buried, until he found a new patron Vincenzi's protectors in Rome seem to have been Benedetto Castelli and Giovanni Faber, two men linked to Galileo and the Lincei. Both refer to Vincenzi as the inventor of almost miraculous artefacts, the wind gun and the portable fountain, describing the demonstrations he carried out in his Roman workshop in 1627, and publishing this news a little more than a year later in 1628 . Castelli makes only a passing reference that is hidden away in his book on hydraulics, while that of Faber is much longer and more personal, appearing in one of the most outstanding works published by the Accademia, the Animalia Mexicana. Both Castelli's book and Animalia Mexicana bear a dedication to the Barberini family. Of the two, however, Castelli's allusion seems to be almost fortuitous - probably because it appears in a relatively short work in Italian, albeit one that would be reprinted several times, translated into French and English, and reproduced years later by Boyle. Faber's reference instead appears in a long, dense tome written in Latin and addressing an apparently unrelated subject, that would only be partially translated by Boncompagni, and most of which would remain unpublished. However, if we add to this the correspondence of Faber conserved in the archives of the Accademia dei Lincei, the scope of Vincenzi's Roman activities becomes slightly clearer.

In 1626 Benedetto Castelli (1577-1643), disciple and collaborator of Galileo, was summoned by Urban VIII to teach mathematics at the Sapienza. A hydrau-

36 Thomas J. Dandelet, La Roma española (1500-170o) (Barcelona: Crítica, 2002), pp. 231-234.

37 Biagioli, Galileo cortesano (cit. note 29), pp. 303-328.

38 David Freedberg, The Eye of the Lynx: Galileo, His Friends, and the Beginnings of Modern Natural History (Chicago/London: The University of Chicago Press, 2002). 
lic engineer and specialist in "affari d'acque" who also served as mathematician to the Pope in the Papal States, Castelli became involved in debates over such problems as how to control the waters from rivers flowing into the Venetian Lagoon and the reclamation of the Pontine marshes that Pope Barberini hoped to drain, as Pope Sixtus v had done before him. In 1628 Castelli published Della Misura dell'Acque Correnti, (Fig. 2) a book regarded at the time as the cornerstone of hydrodynamics ${ }^{39}$ and in which he refers to "Vincenzo Vincenti urbinate" as the inventor of the wind gun and the portable fountain. Both devices were based on the physical attributes of air and water and on the fact that the former can be compressed and latter not. ${ }^{40}$

Notwithstanding this, the most fruitful relationship for Vincenzi was without a doubt the friendship that he struck up with Giovanni Faber (1574-1629). Giovanni or Iohannes Faber, a German residing in Rome since 1598, was a doctor at the Ospedale di Santo Spirito in Sassia, a professor at the Sapienza - as was Castelli - and director of the Papal Botanical Gardens. He had been serving as secretary of the Accademia dei Lincei since 1611 and as the intermediary between a large number of German noblemen and the Papal City. ${ }^{41}$ Faber was renowned for his so-called "anatomical museum" and was on excellent terms with many of the northern European artists then living in Rome.

Interestingly, the most exhaustive account of Vincenzi appears in Animalia Mexicana, an anticipation of the Tesoro Messicano that was published by the Lincei in 1651. The aim of the Tessoro Messicano was to collate and present the material collected by the protophysican of the Indies, Francisco Hernández, during an expedition to New Spain between 1571 and 1577. This material, which was abridged by Nardo Antonio Recchi between 1580 and 1582 on the order of

39 Massimo Bucciantini, "Il trattato della misura dell'acque correnti di Benedetto Castelli. Una discussione sulle acque all'interno della scuola galileiana," Annali dell'Istituto e Museo di Storia della Scienza di Firenze, 1983, 8:103-140; Cesare S. Maffioli, Out of Galileo. The Science of Waters 1628-1718 (Rotterdam: Erasmus Publishing, 1994) and La via delle acque (1500-1700):Appropriazione delle artie trasformazione delle matematiche (Firenze: Olschki, 2010).

40 " [...] come si vede per esperienza nell'Archibugio a vento, inventato a nostri tempi da M. Vincenzo Vincenti Urbinate, la quale condizione dell'aria di potere essere condensata si vede ancora nelle Fontane portatili del medesimo M. Vincenzo: le quali Fontane schizzano in alto l'acqua a forza i aria compressa, la quale mentre cerca ridursi alla sua naturale constituzine, nel dilatarsi fa quella violenza." Benedetto Castelli, Della misura dell'acque correnti di Don Benedetto Castelli (Roma: Stamparia Camerale, 1628), pp. 17-18. On Faber, see Irene Baldriga, L'occhio della Lince. I primi lincei tra arte, scienza e collezionismo (1603-163o) (Roma: Accademia Nazionale dei Lincei, 2002), especially pp. 171-233. 


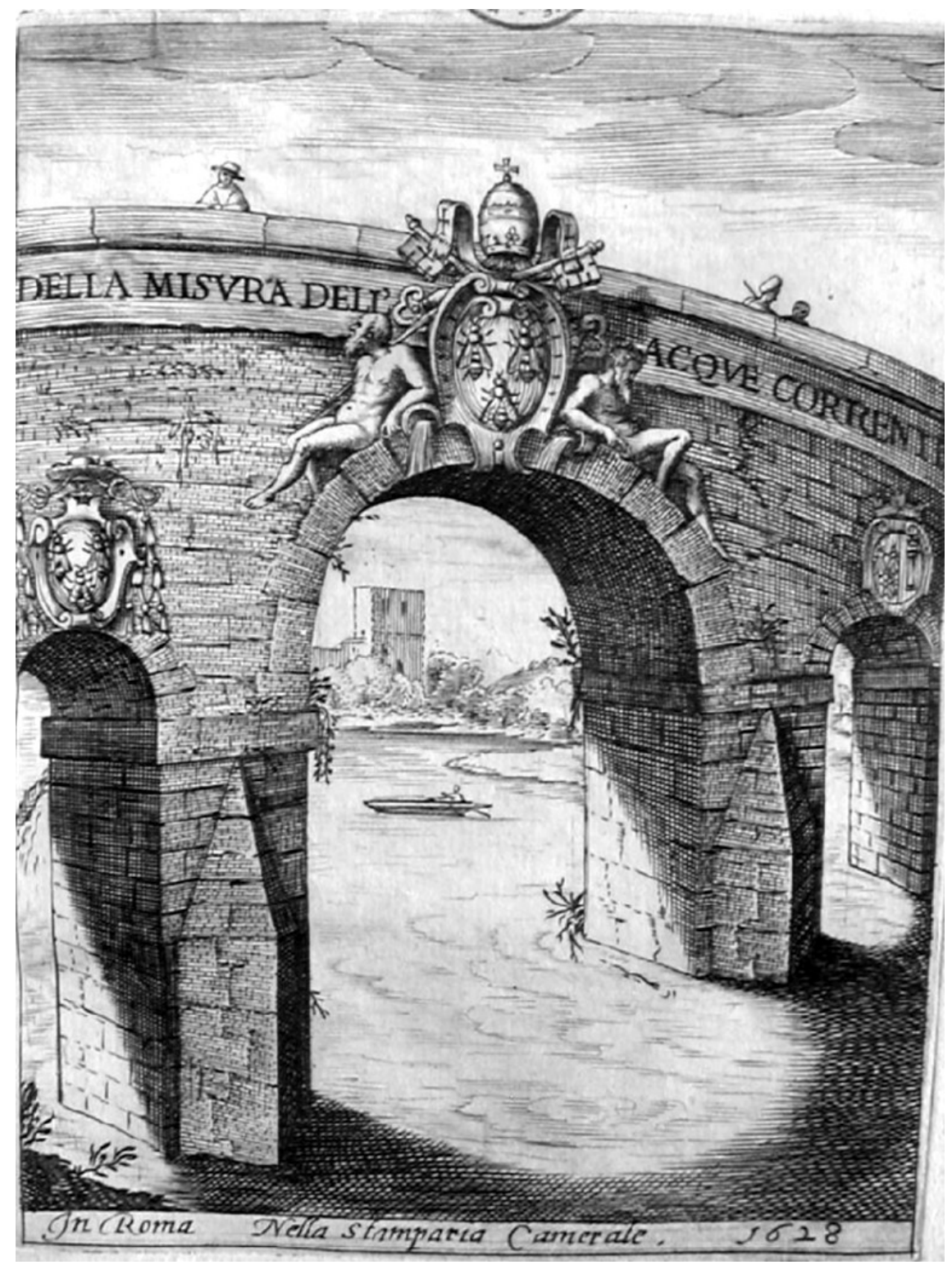

FIgure 2 Benedetto Castelli, Della misura dell'Acque Correnti (Roma: 1628)

Philip II, eventually reached Naples and then Rome. As a foretaste, in 1628 Faber published Animalia Mexicana (Fig. 3), dedicating it to Cardinal Francesco Barberini.

Faber made the most of the material that was available to him by including in Animalia lengthy digressions on many of his Roman connections, includ- 


\section{O A N N IS F A B R I LYNCEI BAMBERGENSIS,}

MEDICI ET PROFESSORIS ROMANI,

Et iam quinque Summis Pontificibus ab Herbarijs Ptudijs

ANIMALIA MEXICANA

Defcriptionibus, fcholijsq. expofita.

THESAVRI RERVM MEDICARVM NOVAE HISPANIAE, $S$ E $V$

PLANTARVM, ANIMALIVM, MINERALIVM MEXICANORVM

H I S T O R I AE

FRANCISCI HERNANDI NOVI ORBIS MEDICI PRIMARII, ET

XARDI ANTONII RECCHI MONTECORVINATIS

Philippi Il.Hi/paniarum of Indiarum O c.Regis Medici, or Neap.Regni Archiatri generalis : a Lynceis,notis, commentarÿs, ambiarÿs illuffunen, of edite : Q Cegate failicet primi Tomi pars. Al Conim. AD ILLVSTRISS. ET REVERENDISS. D. D.

\section{FRANCISCVM BARBERINVM}

\section{S. R. E. CARD. AMPLISSIMVM:}

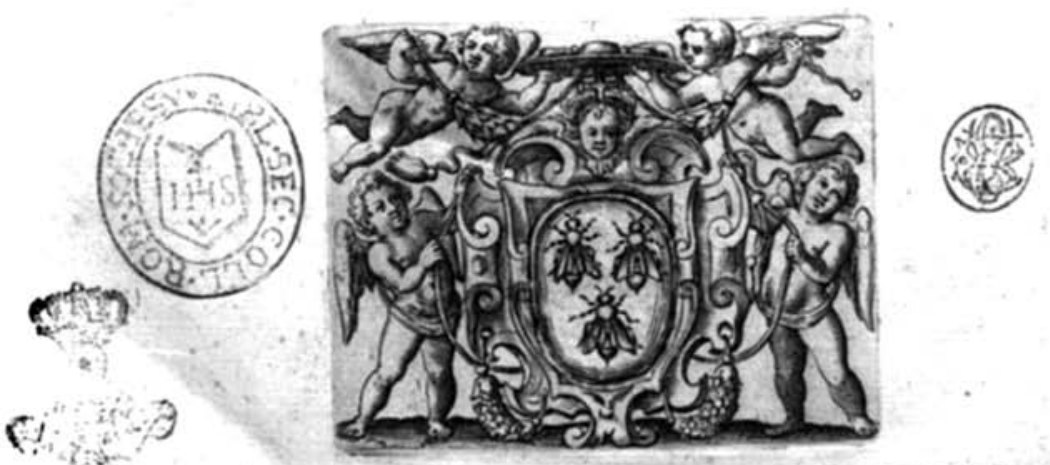

ROM AE, Apud Iacobum Mafcardum: MDCXXVIII.

Cum priuilegijs Summi Pontificis,S.Cxf. Maieftatis, Chriftianifs. Regis Gallix, \& Magni Ducis Etrurix.

S V PER I O R V M PER M IS S V.

FIGURE 3 Iohannes Faber, Animalia Mexicana (1628) 
ing artists such as Rubens, Adam Elsheimer, Filippo Napoletano and Paul Bril, and the pharmacist Enrico Corvino, and descriptions of the gardens of Cardinal Odoardo Farnese, Carlo Emanuele Pio di Savoia, and the Villa Scipione Borghese. ${ }^{42}$

The reference to Vincenzi is to be found in the chapter dedicated to the Cuapapalcatl or Mexican Camaleon, ${ }^{43}$ where the possibility that air condenses to form dew is established. "Vincentius Vincentii Urbinas" is cited as the inventor of the bombardam manuariam or bombardam pneumatica made in Rome in 1627. The gun fired clay or lead balls without the need for gunpowder, being propelled solely by means of air pressure, and "res, quae doctos, indoctos, magnates aeque ac idiotas ita in admiratione rapuit, ut cateruatim ad aedis ipsius quotidie peruolent hoc artis miraculu spectaturi;" viz. the learned and the ignorant, magnates and plebeians gathered in their masses at the home of Vincenzi to witness that portent of art. ${ }^{44}$

For his part, Faber was well aware that the idea for a similar device had already been conceived by Giovan Battista della Porta in his Magia Naturale. Della Porta took it upon himself to explain to Federico Cesi that similar instruments were described in his Taumatologia. ${ }^{45}$ Original or not, this wind gun - which Castelli called an archibugio a vento and Buoncompagni called a schioppo pneumatico - was unquestionably Vincenzi's most well-known invention. Faber cites the "admiring" multitudes eager to witness that "portent of art" in his workshop, an invention that soon became a much sought-after item by the rich and powerful. He closes with an account of the rulers who were fortunate enough to possess one of Vincenzi's devices, citing the King of Spain and the King of Poland, and describing how he himself commissioned one for Leopold v, Archduke of Austria.

In addition to the account in Animalia Mexicana and the correspondence conserved in the archives of the Accademia dei Lincei, our knowledge of the relationship between the two men is rounded off by the fact that Faber became

42 On the cultural milieu of Faber that forms the basis of the Animalia Mexicana, see Sabina Brevaglieri and Elisa Andretta, "Storie naturali a Roma fra Antichi e Nuovi mondi. Il 'Dioscorides' di Andrés Laguna (1555) e gli 'Animalia Mexicana' di Johannes Faber (1628)," Quaderni Storici, 2013, 48:43-87.

Ioannis Fabri, Animalia mexicana descriptionibus (Roma: Iacobum Mascardum, 1628), p. 737 .

44 Faber's Latin text was partially translated into Italian by Baldassarre Boncompagni, Intorno ad alcuni avanzamenti della física in Italia nei Secoli XVI e XVII (Roma: Tipografia delle Belle Arti, 1846), p. 19.

45 Boncompagni, Intorno ad alcuni (cit. note 44), p. 20. 
a sort of agent for Vincenzi, mediating between him and various noblemen. Among these, Leopold v (1586-1632) must have played an important role..$^{46} \mathrm{He}$ was one of the first to ask Galileo his opinion of the three comets that had traversed the sky in 1618; the following year the astronomer Mario Guiducci published his Discorso delle comete, with a dedication to the archduke in explicit acknowledgement of Galileo as the author of the hypothesis. Leopold was what one might call an amateur collector of mathematical instruments; on 23 May 1618 Galileo sent him as a mark of his appreciation of the archduke's visit in March two telescopes and an instrument of his own invention in the form of a "copricapo, il celatone, per il calcolo della longitudine in mare" (a piece of headgear that allowed one to calculate longitude at sea), as well as copies of his Lettere sulle macchie solari and a letter to Cardinal Alessandro Orsini discussing the ebb and flow of the sea. ${ }^{47}$

In a missive sent in 1627 , Faber informed the archduke about "un archibugio a vento che ha fatto un urbinate mio amico [a wind gun that my friend from Urbino has made]," describing how the device worked and how it had become a coveted item for rulers and collectors and a popular dono or diplomatic gift. The Grand Condestable Colonna had one sent to Spain;8 it had been personally tested by Cardinal Borja; and one was being made for Antonio Santa Croce, the new Apostolic Nuncio to Poland. ${ }^{49}$ From accounts published after Animalia we can glean that it was Colonna who had given the King of Spain his wind gun and that the new Apostolic Nuncio to Poland presented a wind gun to King Sigismund III Vasa.

On 10 April 1627 Giovanni Faber sent a letter to Leopold v in which he refers to the archduke's request for a wind gun, that "cosa mirabile [marvellous thing]," noting that the master artisan commissioned to make it had put up his prices, the Apostolic Nuncio to Poland having paid some 50 scudi. ${ }^{50}$ The wind gun was ready by 7 May, but as "no fu totalito al suo gusto [it was not

46 Leopold, Bishop of Passau and Strasbourg, was later granted the lordship of Tyrol and married Claudia de' Medici.

47 Stefania Elena Carnemolla, "Un dono per l'arciduca," Lega Navale Italiana, 2013, 11-12:3638 .

48 In 1611 Filippo I Colonna (1578-1639) was named Grand Constable of the Kingdom of Naples, retaining the title until his death in 1639 . Surely the wind gun must have been sent to Philip IV as a gift.

49 Biblioteca dell'Accademia dei Lincei e Corsiniana (B.A.L.C.), Fondo Johannes Faber, Corrispondenza, Filza 413, 301r.

$50 \quad$ B.A.L.C., Fondo Johannes Faber, Corrispondenza, Filza, 413, 302r. Letter dated 10 April 1627. 


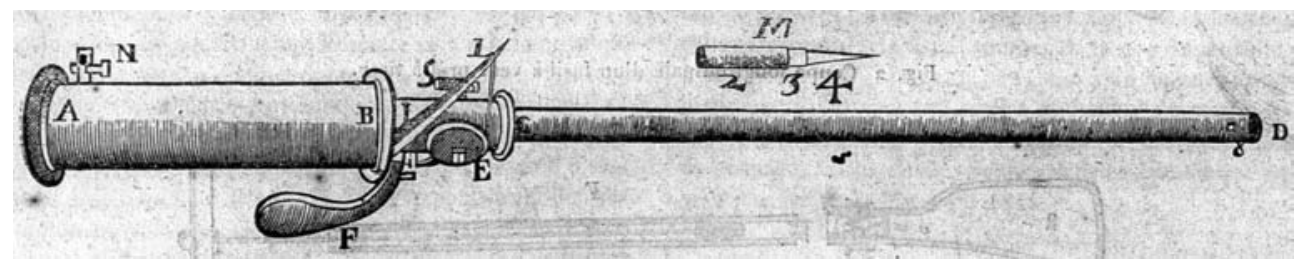

FIGURE 4 Wind-gun by Marin le Bourgeois, in David Rivault de Flurance, Elements d' artillerie $(1608)$

entirely to his taste]," the artisan was making another "cha sara di maggior perfetta [that would be more perfect]." This exemplar of Vincenzi's wind gun must have been sent off in September, since a document dating to around that time entitled "Occorente in torno all'archibugio da vento,"51 which is nothing less than a manual with instructions for the use and maintenance of the wind gun, has been found among Faber's correspondence.

As a matter of fact, both the wind gun and the portable fountain were simply attempts to recreate devices described in ancient times. With regard to the wind gun, Filone Bizantino described a similar contrivance invented by Ctesibius of Alexandria, Hero's teacher. In his own time, different countries claimed the credit for inventing this artefact. Johann Heinrich Zedler ascribed the invention of the windbuchse to the gunsmith Guter in Nuremburg in 1530. As for France, David Rivault, a mathematician who wrote a treatise on the elements of artillery for Louis XIII, referred to the arquebuse d'air or fusil a vent made by Marin le Bourgeois of Lisieux, "homme de plus rare jugement en toutes sortes d'inventions" 52 (Fig. 4). The wind gun allowed generations of naturalists to experiment with the elastic nature of air. ${ }^{53}$ In the framework of research into the elasticity of air, Marin Mersenne discussed the functioning of

51 B.A.L.C., Fondo Johannes Faber, Corrispondenza, Filza, 413, 326R. The undated document is to be found between two letters sent by Leopold of Austria from Ensisheim on 2 and 7 September 1627 , respectively.

52 David Rivault de Flurance, Les éléments de l'artillerie concernants tant la théorie que la pratique du canon: augmentés en cette nouvelle édition et enrichis (Paris: Adrien de Beys, 1608) and Edouard Charton, "Le fusil à vent de Marin Bourgeois et l' aerotone de Ctesibus," Le Magasin Pittoresque, septembre 1848, 16:294-296.

53 Arne Hoff, Airguns and other Pneumatic Arms (London: Barrie and Jenkings, 1972), Jim Bennett, "Wind-gun, Air-gun or Pop-gun: The Fortunes of a Philosophical Instrument," in The Mindful Hand: Inquiry and Invention from the Late Renaissance to Early Industrialisation, edited by Lissa Roberts, Simon Schaffer, Peter Dear (Chicago: The University of Chicago Press, 2007), pp. 221-245. 
the wind gun with reference to its rarefaction and condensation in his Cogitata of 1644, while Robert Boyle included Castelli's account and credited Vincenzo Vincenzi with its invention in his writings. ${ }^{54}$

Portable fountains had also been described in the past; the story goes that such a fountain was one of the first gifts that Pizarro received from Atahualpa; Giovanni Frey, the father-in-law of Alberto Durero, is recorded as having fashioned some portable fountains; and in Vincenzi's time Giovanni Coccapani supplied Cosimo II with various exemplars.

Faber's letter to the archduke, dated 10 April 1627, provides us with yet further information on Vincenzi; Faber recommended him "per ingegnere delli fontane, che il Sr. Card. Pio fa fare belissimi nel suo giardino dietro il Tempio della Pace [to invent some fountains, that il Sr. Card. Cardinal Pio would use to embellish his garden behind the Temple of Peace]." 55 Baldriga has cited this passage, but omitted the name of the engineer - Vincenzo Vincenzi. The villa to which Faber was referring (now known as Villa Silvestri-Rivaldi) had been purchased by Cardinal Carlo Emanuele Pio di Savoia from the heirs of Cardinal Lanfranco Margotti. During that time the cardinal completely renovated the garden, giving it a new look and enhancing its role as a belvedere overlooking the Coliseum, and ordered the building of a casino novo with a double façade lined with statues. ${ }^{56}$ It is difficult to say whether Vincenzi ended up working for Cardinal Pio di Savoia at one time or another, but Giovanni Faber was evidently familiar with the versatility of the hydraulic engineer and fontanaro from Urbino, whose design of contrivances for Roman gardens led him to experiment with air compression and to perfect ingenious gadgets, some of which had been known in the literature since Antiquity.

54 Marin Mersenne studies the rarefaction and condensation of air and explains the "scopetum pneumaticum." Cogitata, Physico-mathematica. Hydraulica, pneumatica et mechanica phaenomena (Paris: Antoine Bertier, 1644), pp. 149-155.

55 The letter is cited in Baldriga, L'occhio (cit. note 41), p. 199.

$5^{6}$ Enzo Bentivoglio, "La villa del cardinale Carlo Emanuele Pio di Savoia al Colosseo. Il “Casino Novo" e Francesco Peperelli," Quaderni del Dipartimento Patrimonio Architettonico e Urbanistico, XIV, 2005, 27-28:5-12. The complex's renovation is attributed to the architect Francesco Peperelli, while the sculptor Giacomo Spagna worked on the statues. 


\section{Vincenzo Vincenzi, Engineer to Cardinal Borja}

We do not know if Vincenzi was ever in the service of Cardinal Pio di Savoia, although soon afterwards he was to be found working for Cardinal Gaspar Borja, whose acquaintance he must have made when the cardinal tested and purchased one of his wind guns.

It comes as no surprise that within the circles of patronage of the Rome of Urban VIII, Vincenzi ended up in the service of Cardinal Gaspar de Borja. Gaspar de Borja y Velasco (1580-1645), son of the 6th Duke of Gandía, had been living in Rome since being awarded the red hat in 1611 . From 1616 to 1619 he was the ambassador of Philip III to the Holy See, in 1620 he was briefly Viceroy of Naples, and from 1632 to 1635 he once again filled the post of ambassador in Rome. ${ }^{57}$ (Fig. 5)

During the years in which he was presumably Vincenzi's patron, between $1627 / 30$ and 1635 , his responsibilities were more those of a diplomat in the service of the Spanish Court than those of a Prince of the Church. He played a leading role in the so-called "scandal of the consistory" of 8 March 1632, in which he accused Urban VIII of being too lenient with heretics by refusing to support the military enterprises of the Spanish king against the Protestants in Germany. The intervention of the Pope's brother and Cardinal Sandoval was so violent that the guards had to be summoned. This incident led to his departure from Rome on 29 April 1635.

While Borja's artistic patronage ${ }^{58}$ and the characteristics of his collection ${ }^{59}$ have been the object of study, scant attention has been paid to the circles in which he moved. During his time in Rome, the cardinal first resided at the Palazzo Rucellai located in Strada del Corso, and then in the Piazza dei Santi Apostoli, where musical and theatrical performances were staged. The cardinal surrounded himself with a large court that included Diego de Saavedra Fajardo, who served as his secretary before pursuing a career as a diplomat and political

57 Silvano Giordano, "Gaspar Borja y Velasco rappresentante di Filippo III a Roma," Roma moderna e contemporanea, 2007, 1-3:157-185.

58 David García Cueto, "La acción cultural y el mecenazgo de los cardenales-embajadores de Felipe IV en Roma: Borja y Albornoz," in I rapporti tra Roma e Madrid nei secoli XVI e XVII: arte, diplomazia, e politica, edited by Alessandra Anselmi (Roma: Gangemi Editore, 2015), pp. $340-361$.

59 Marià Carbonell, "Colleccionistes borgians en època barroca: una dama, un cardenal, un poeta," Revista Borja. Revista de l'Institut Internacional d'Estudis Borgians, 2013, 4:439462 . 


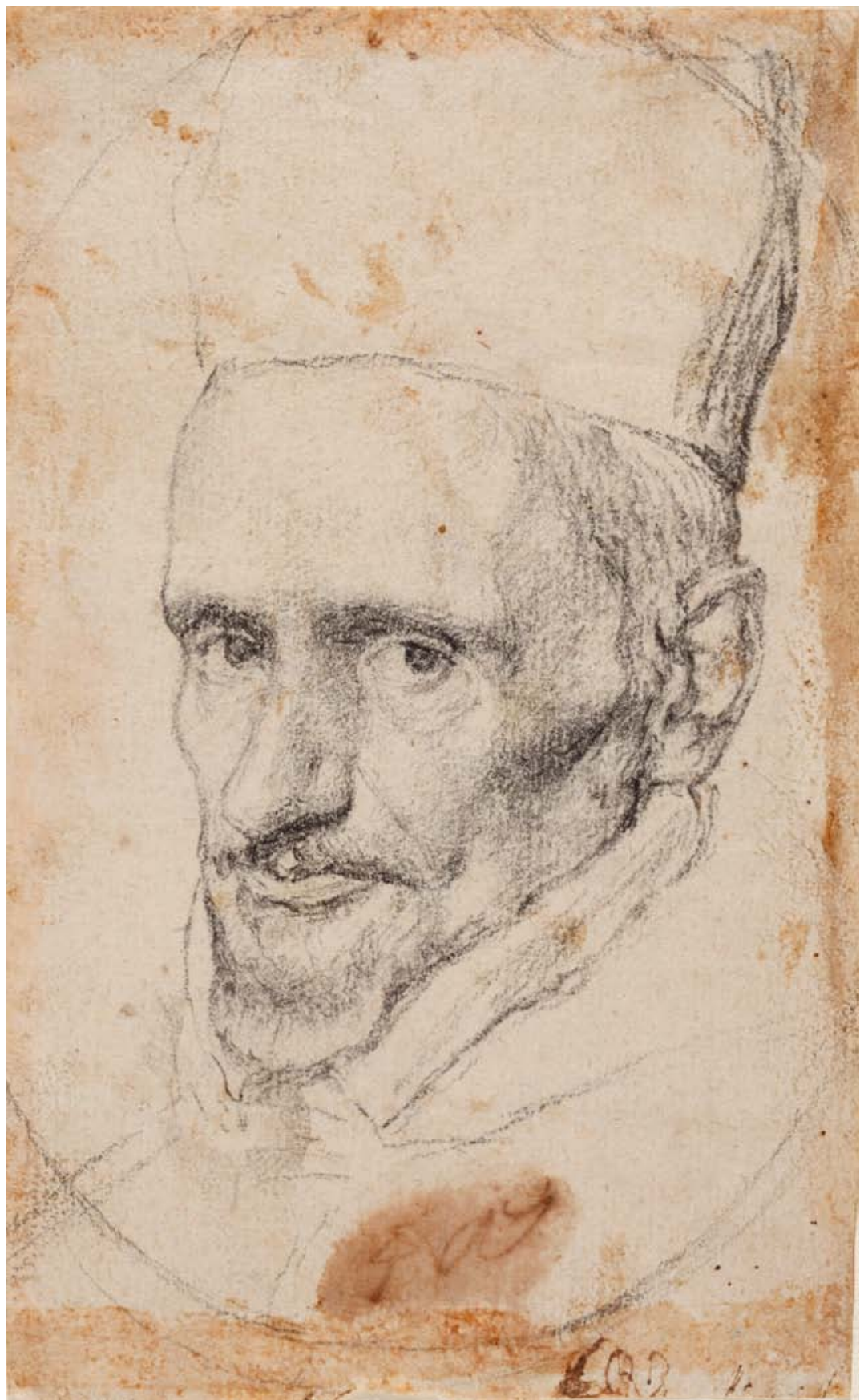

Figure 5 Diego Velazquez, Portrait of Cardinal Gaspar de Borja, (h. 1643-145) REAL ACADEMIA DE BELLAS ARTES DE SAN FERNANDO, MADRID 
theorist, ${ }^{60}$ and his physician Gabriel da Fonseca, who would later become the personal physician to Innocent $\mathrm{x} .{ }^{61}$

It has been frequently noted that Cardinal Borja sat on the tribunal that condemned Galileo, and emphasis has been placed on the fact that its creation had partly to do with the zeal kindled by the scandal of the consistory provoked by the cardinal, but what has not been sufficiently highlighted is his prior relationship with Galileo and other members of the Accademia dei Lincei. During Borja's time as ambassador he played the role of intermediary between Galileo and the Spanish Court. In 1611 Galileo had offered the Spanish Crown a new method of determining the longitude of a ship at sea that would facilitate ocean navigation, a proposition that was withdrawn in 1620; at the same time he presented the King of Spain with the gift of a telescope. We also know that when in 1620 he was promised an income of 2000 ducats, Galileo asserted that at the residence of Cardinal Borja he had been told that the award would be 6000 ducats and the Cross of St. James. ${ }^{62}$

The negotiations over Galileo's navigational instrument, which were never successfully concluded, took place at Cardinal Borja's residence, and the intermediary was the aristocrat and poet Virginio Cesarini, who had close ties with both the cardinal and Galileo. Cesarini joined the Accademia dei Lincei in 1618, at the same time as Giovanni Ciampoli, another man close to the cardinal. The two were involved, alongside Giovanni Faber, in the preparations leading up to the publication of Galileo's Il Saggiatore in 1623. According to Biagioli, both men could be considered "beneficiaries of Urban VIII and mentors of Galileo." ${ }^{33}$ Cesarini and Ciampoli were appointed to important posts - Master of the Chamber and Secret Steward, respectively - when Urbano viII occupied the Throne of St. Peter. Cesarini died soon afterwards, while Ciampoli ended

6o When in Rome, Saavedra Fajardo served as Counsel of the Chamber, Secretary to the Ambassador and of the Cipher, State and War Secretary in Naples, and the King's agent, in each case at the behest of Borja. Quintín Aldea, "Nobleza y poder en el Siglo de Oro: Saavedra Fajardo en la constelación de los Borja," in Manuel Fraga: Homenaje académico, Vol. 1 (Madrid: Fundación Cánovas del Castillo, 1997), pp. 299-327.

61 James W. Nelson Novoa, "Medicine, Learning and Self-Representation in Seventeenthcentury Italy. Rodrigo and Gabriel da Fonseca," in Humanismo, Diáspora e Ciência séculos XVI e XVII, edited by Antonio Andrade, Joao Torrao, Julio Costa and Jorge Costa (Oporto: Camara Municipal do Porto, 2013), pp. 213-232.

62 On the negotiations between Galileo and the Spanish Crown pertaining to the measurement of longitude, see the correspondence in Opere di Galileo Galilei, Vol. II (Milano: Niccolò Bettoni, 1832), with the reference to this conversation on p. 137 .

63 Biagioli, Galileo cortesano (cit. note 29), p. 54. 
up being expelled from Rome in a confusing sequence of events in which his links with the pro-Spanish party led by Borja seem to have been a determining factor.

The presence of Saavedra Fajardo, Fonseca, and above all Cesarini and Ciampoli, points to Borja being more than a bystander as he was in no way unfamiliar with the scientific developments that were unfolding in Rome. We know that he purchased a wind gun in 1627 , around the time when, as Vincenzi himself records, he made the acquaintance of the engineer from Urbino. As will be seen, documents show that this relationship was bolstered by a shared objective, that of reclaiming Gandía's salt marsh, but it seems quite probable that Vincenzi was asked to provide other services as well.

It is important to take into account that at practically the same time that Vincenzi established himself in Rome and had begun to negotiate his trip to Gandía, another fontanaro set out for the Spanish Court. In 1625 the CountDuke of Olivares requested the Ambassador of Spain to the Holy See, Ruy Gómez de Silva y Mendoza, Duke of Pastrana, to look for a fontanaro willing to travel to Spain. So in 1626 the Florentines Cosimo Lotti, Pier Francesco Gandolfi, Giulio de Lorenzo and Giulio de Chimendi arrived in Spain with the duke's entourage. Before departing, Gandolfini made drawings of the fountains of Rome, Frascati and Tivoli on the ambassador's orders. ${ }^{64}$ Besides working for him as a hydraulic engineer, Lotti gave Philip IV an automaton - the head of a satire with which to frighten visitors to the Alcázar ${ }^{65}$ - and drew up the project for a garden full of automata, which he called the Tempio dell'Eternità. ${ }^{66}$ Episodes of this kind would not have not been unfamiliar to the House of Gandía, since Juana Enríquez de Velasco y de Aragón, the cardinal's mother, was the Queen's principal chambermaid until her death in 1627, and her brother, Carlos Francisco, the 7th Duke, was named High Steward in 1630, a post that he occupied until his death in $1632 .{ }^{67}$

64 David García Cueto "El viaje a España de Cosme Lotti y las fuentes de Roma, Tívoli y Frascati," Archivo Español de Arte, 2007, 319:315-322.

65 Jorge Fernández Santos, "Ianua Palladis, Templum Virtutis Honorisque: An Instructional Garden of Automata devised by Cosimo Lotti for the Count-Duke of Olivares," in L'Arte del Dono: Scambi artistici e diplomacia tra Italia e Spagna, 1550-1650, edited by Marieke Von Bernstorff and Susanne Kubersky-Piredda (Roma: Silvana, 2013), pp. 183-199.

66 David García Cueto, "L'Introduttione al Tempio dell'Eternità. Un giardino allegorico ideato da Cosimo Lotti per Filippo Iv Re di Spagna," in Giardini storici. Artificiose nature a Roma e nel Lazio, edited by Cecilia Mazzetti di Pietralata (Roma: Gangemi, 2009), pp. 201221.

67 Henar Pizarro Llorente, "Bisnieto de un santo. Carlos Francisco de Borja, vir Duque de 
Vincenzi must have first met Cardinal Gaspar de Borja in Rome around 1627 . At that time the cardinal had already purchased a wind gun, as we have seen in the letters sent by Faber to Archduke Leopold on 23 April of that same year, and this gun would remain in his possession until the end of his life, as is shown by an inventory made after his death. ${ }^{68}$ This information coincides with the dates provided by another important source, namely the correspondence between Vincenzo Vincenzi and the Querinis, Venetian patricians who had requested his services in Rome. ${ }^{69}$

Although he belonged to the lesser nobility, Carlo Querini achieved a certain degree of social advancement after his appointment to the Council of Forty, one of the Republic of Venice's highest constitutional bodies, whose criminal section was responsible for administering criminal justice in the Veneto. But Querini's peace of mind was shattered when in 1626 he was accused by the Inquisition of abusing his position to obtain ecclesiastical favours. He fled Venice and, after journeying through several Italian cities, established himself in Rome, where he remained under the protection of the Jesuits and a number of Spanish cardinals, such as Alfonso de la Cueva. ${ }^{70}$ In an attempt to clear his name and obtain the pardon of the Most Serene Republic of Venice by the provision of an exceptional service, he sought out scholars and men of science of the type that then abounded in the city of Rome, and asked them to come up with useful inventions for Venice. This is when Vincenzo Vincenzi takes centre stage, responding to the request made by Carlo in Rome by writing to Silvestre Querini, who had remained in Venice serving as his brother's intermediary with the Council of Ten. ${ }^{71}$

Gandía, Mayordomo Mayor de la reina Isabel de Borbón (1630-1632)," Librosdelacorte.es, 2014, monográfico 1, año 6:107-135.

68 This wind gun figures among the objects found in the inventory conducted after the death of Cardinal Gaspar de Borja, Archivo Histórico Nacional, (AHN) sección Nobleza, Osuna, C.1040, D.1, Inventario de los bienes del cardenal Gaspar de Borja, Madrid, january 1646, "un arcabuz de viento y otros dos de caza para su eminencia."

69 Anna Pizzati, "Da magistrato a vescovo: il fallito passagio di carriera di Carlo Querini, nobile povero del primo Seicento," in Per Marino Berengo, edited by Livio Antonielli, Carlo Capra, and Mario Infelise (Milano: Franco Angeli, 2007), pp. 299-321.

70 Alonso o Alfonso de la Cueva, Marquis of Bedmar, had served as the Spanish ambassador to Venice since 1609. The closeness to de la Cueva could only augment the suspicions of the Venice Republic because he had been accused of conspiracy against the Republic together with the Viceroy of Naples in 1618. Nicholas Davidson, "Hispanophobia in the Venetian Republic," in The Spanish Presence in Sixteenth-Century Italy. Images of Iberia, edited by Piers Baker-Bates and Miles Pattenden (Oxford: Ashgate, 2015), pp. 29-42.

71 Biblioteca del Museo Correr of Venice, CorrerVe, Codice Cicogna 2799, cc. 156-162. 
Around October 1629, Carlo Querini visited Vincenzi's workshop in Rome, which may be seen as a sort of 'showroom' where demonstrations of his chief invention, the wind gun, could be held. Carlo had taken interest in this invention, and considered acquiring a hunting arquebus identical to two that the abbot of the church of St. Zeno in Verona, Pietro Contarini, had already taken to Venice. ${ }^{72}$ Therefore this invention was already known to the Venetians and Carlo Querini suggested that Vincenzi show him others that might be of interest to the Doge and his circle. Apparently they discussed four that might be used for warfare, about which nothing more is recorded as these were "secret inventions" of potential interest to the rulers of a sovereign state. ${ }^{73}$ Querini opened negotiations aimed at eliciting a judgment and decision from the Council of Ten as to whether it would receive Vincenzi in Venice, examine his inventions and acquire some exemplars. Silvestro Querini's mediation must have taken several months, since not until April 1630 was it confirmed that Venice had accepted the proposal of Vincenzi's journey and stay. But during this time the Italian engineer's situation had changed.

While waiting for Venice's reply, Vincenzi had continued to engage in the tasks for which he had made a name for himself in Rome, primarily projects related to hydraulics. Since approximately 1627 he had maintained his contacts with Cardinal Borja, visiting him frequently at his home, where they discussed issues relating to water, gardens, fountains, and wells, and various inventions of his, as is mentioned in his correspondence. ${ }^{74}$ We know that the cardinal lived in the city centre, in the Piazza dei Santi Apostoli, so presumably all of this work was carried out on the grounds of villas in the environs of Rome, to which many of the ecclesiastics residing in the Eternal City withdrew to

72 CorrerVe, Codice Cicogna, 2799, 157r, “[...] venne per sua natural benignita forse otto mesi, sono un giorno alla mia botegha, l'ill.mo Sig.r Carlo Querini fratello di v. s. Ill.ma. e vedendo l'Archibuggio a vento di mia inventione, quello cioè da caccia, simile a due che ne sono venuti a Venetia portativi da Ill.mo fratelli abbate de san Zeno Contariri e che l'archibuggio da guerra nessuno per ancora l'ha veduto meno havuto, e sentendomi ragionare di molte cose simile, mi dimandò si io andasi a servire la serenessima sua Repubblica overo se io li dareile inventioni e i segreti de quali si era ragionato; dissi di si e conforme all'instanza [...]."

73 CorrerVe, Codice Cicogna, 2799, 157r, “[...] Il Sig. Carlo Querini Ill.mo mi scrisse che in Venetia era stata pigliata punta nell'Eccellentissimo Consiglio di $\mathrm{x}$ accettando l'offerta mia di dare alla Serenissima Repubblica le quattro inventioni da guerra [...]."

74 CorrerVe, Codice Cicogna, 2799, 156r, "[...] Dico dunque che circa tre anni sono presenti il Signor Cardinal Borgia, che io mi dilettava d'acque e che oltre le fontane da camera insolite, et anco da giardini, oltre l'inventione d'alzarne da pozzi anco profondi e da fiumi et da altri ridotti per delitie e per utile di adacquar champagne [...]." 
find some peace and quiet. In the past the Villa d'Este in Tivoli and the Villa Silvestri-Rimaldi, the latter actually located in the city itself, had served this purpose.

Throughout this period, Cardinal Borja's chief intention had been to convince Vincenzi to travel to Spain ${ }^{75}$ in order to drain a salt marsh on his landed estates in the Duchy of Gandía. For some time Vincenzi refused on the grounds that he did not have enough information to accept the commission and that he would only be willing to make the trip if he were first provided with a map depicting the topography of the land and a detailed report on the problem. Judging this to be nearly impossible because he thought that no one would be capable of supplying the necessary information, Cardinal Borja sought to convince Vincenzi to make the journey to Gandía and to evaluate the situation in person, offering him a generous compensation even if, once there, he found that the salt marsh was impossible to drain..$^{76}$ But Vincenzi dug in his heels, posing a series of questions on the state of the palude to which apparently no one had the answers. Indeed the cardinal, who had not visited his estates for some time, was aware that things might not be as he remembered them. This deadlock continued untilJanuary 1630 , when the cardinal sent for Vincenzi again, for he was now in a position to answer the questions previously raised by the engineer. During this time he had succeeded in persuading "un prete zoccolante [a clog-wearing priest]" - that is, a Franciscan Friar Minor - to come from Spain with a map of the land. ${ }^{77}$ This could have been a friar from the recently founded Convent of San Roque in Gandía, which was built on the orders of the 5 th Duke, Carlos de Borja, in 1591, and where several members of the Borja family had taken holy orders. ${ }^{78}$ The map, although imperfect, gave Vincenzi some idea of the options open to him, while dispelling some of his doubts.

75 CorrerVe, Codice Cicogna, 2799, 156r, “[...] mi fece chiamare detto Sig. Cardinal Borgia e mi dimandò se mi dava l'animo di rasciugare una sua palude in Spagna e cominciò a descrivermene il sito e la qualità: li risposi che sopra di quelle sole informationi io non poteva determinare cosa alcuna e che però se ne facesse mandare la pianta che all'hora havrei datta la mia opinione: [...]."

76 CorrerVe, Codice Cicogna, 2799, 156r, “[...] Voleva mandarmi all'hora in Spagna acciò che me stesso vedessi il luogho, senza aspettarne altre informationi, poiché non credeva di trovar colà persona che fosse habile al bisogno; replicai che senza qualche miglior notitia, non mi risolveria a muovermi di qui, per non trovare dell'impossibilità e correre risigo, che si credesse non darmi l'animo di operare."

77 CorrerVe, Codice Cicogna, 2799, 156v, “[...] Ho passarono molti giorni, che comparne qua un prete zoccolanteIl quale porto certa pianta piu casualmente fata."

78 Among others, Francisco (born in 1575), son of Francisco Tomás de Borja y Centelles, vI Duke of Gandía. 
Despite his not being completely sure that his land reclamation scheme would be a success, he accepted Cardinal Borjs's proposal and began to prepare for his trip. In the early stages, the prelate was under the impression that Vincenzi would travel to Spain on one of the galleys in the fleet of his brother, Don Melchor Borja, which was due to set sail in June. However, Vincenzi declared that the summer was not a suitable time of year to conduct a land survey of an area affected by flooding. It was the time when the waters in the salt marsh would be at their lowest and, if any action was taken, it might prove to be insufficient as regards the situation that could present itself during the winter ${ }^{79}$ Acknowledging the reasonableness of his protests, the cardinal agreed to postpone the trip until the end of September or the beginning of October 1630, writing to the Duke of Gandía, the head of the family, in March to inform him of the imminent arrival of Vincenzi, with the commitment to pay him a monthly wage of 25 scudi henceforth.

In the meantime Vincenzi continued to practice his profession. He was summoned by his brother to Orciano da Pesaro (in the province of Pesaro and Urbino, The Marches), his birthplace, to resolve a problem relating to the town's water supply. He was also called in to repair the aqueduct of Mondavio, on which a great deal of money had been spent but which had suddenly stopped functioning. ${ }^{80}$ The aqueduct was fed by a spring located on the outskirts of this town and less than two kilometres away from Orciano da Pesaro. Arriving on 9 April, he had been in the area for 15 days when news arrived that the Republic of Venice had accepted his offer to present his four inventions of warfare.

79 CorrerVe, Codice Cicogna, 2799, 156v, “[...] Cosi dissi al Sig(no)r Cardinale il mio pensiero e fu accettato e volse parola da me d'andare in Spagna per questo effecto, obligandosi di farmi portare dalle galee del Sig. $\mathrm{D}$ (on) Melchior Borgia suo fratello che saria stato circa il presente mese di giugno, replicai che non era bene di andare nell'estate quando l'acqua nella palude si trovasse nella maggior bassezza, ma che conveniva d'esserci nella sua maggiore escrescenza, acciò i rimedi fossero proportionati al maggior male, che se nella estate si facessero ripari secondo l'Arte, conforme al pocho bisogno d'all'hora, nell'inverno potrebbero riuscire scarsi e con pocho utile e minor gusto del Sig. Cardinale e con mio pregiuditio."

8o CorrerVe, Codice Cicogna, 2799, 156v, “[...] Mentre cosi trattava col Signor Cardinale mi fu scritto da mio fratello dalla provincia che la Comunità di Mondavio, terra alla mia provincia un miglio vicina, voleva sanare un acquedotto, che già molti anni havevano fatto con grossa spesa per condurre un'acqua, la quale per questo tempo era corsa et all'hora del tutto cessata e che però andassi come feci, partendo da Roma li 4 del mese d'aprile et ho fatto l'opera." 
Carlo Querini wanted Vincenzi to leave Mondavio immediately for Venice so as to be able to make good on all his promises to the Republic. Vincenzi refused because he first needed to pass through Rome to collect his inventions and put his house in order, but more importantly he alluded to the fact that he needed to brief Cardinal Borja on his current situation. He was not sure that in the time available he would be able to travel to Venice, deliver his secrets, and then be ready to leave for Spain at the beginning of October. Besides, he suspected that if he mentioned that his departure for Venice had to do with inventions of warfare, the cardinal would also show interest in them. Furthermore, he did not wish to forfeit the stipend of 25 scudi that the cardinal had already begun to pay him, in addition to the 16000 scudi he had been promised for his work in Spain. The Querinis were still insisting on the feasibility of demonstrating the workings of at least two of the four inventions in the three months prior to his departure, but apparently Vincenzi declined this commission because the financial terms that he was being offered were also vague, whereas those of the cardinal were assured and raised no doubts. To a certain extent, the fact that he was already being paid on a monthly basis even before his departure bound him to the Cardinal's household and made him a person in the ecclesiastic's employ.

Although the information pertaining to Vincenzo Vincenzi's time in Gandía dates from 1635 and is related to the inspection of the Júcar, as has already been seen, we cannot determine with certainty if he left for Spain in October 1630 or for how long he stayed. Nor do we know of any other references to Vincenzi's sojourn in the region, though the fact that he was recognised as the cardinal's engineer and a resident of Gandía leads us to assume that he remained in Spain for some time, and that perhaps he did indeed work on the salt marsh or on some of the gardens belonging to the Duke of Gandía.

Vincenzi had previous experience in matters relating to land reclamation. This was a vital issue in many areas of Italy where major schemes of bonifiche, as they were called, were implemented. Figuring among the most far-reaching was the attempt to reclaim the Pontine marshes, an area of bogland in the region of Lazio to the southeast of Rome, in which several popes had taken an interest, commissioning different professionals to drain them. ${ }^{81}$ At the time in question, around 1617 the inhabitants of the Pontine Marshes petitioned

81 Domenico Chiari, Il territorio pontino in epoca sistina. Immagini di reforma e vita nello Stato della Chiesa 1585-159o (Terracina: Comune di Terracina, Regione Lazio, 1993) and Domenico Chiari, "Sisto v e la bonifica delle paludi Pontine," in Sisto V. Roma e il Lazio, edited by Marcello Fagiolo e Maria Luisa Madonna (Roma: Istituto Poligrafico e Zecca dello Stato, 1992), pp. 583-602. 
Pope Paul $\mathrm{v}$ to have the reclamation work resumed, but the project was further delayed by lack of funding. In 1637, it was the turn of Urban VIII, who assigned the work to a Dutch company, although this attempt also ended in failure due to the untimely death of Cornelius de Witt, the company's principal director. Fresh attempts were made during the 18th and 19th centuries, until the ambitious project was finally undertaken by the government of Mussolini.

We know that in 1628 Benedetto Castelli devoted a chapter to this problem "Delle considerazione sulla bonificazione delle Paludi Pontine" - in his book Della misura dell'acque correnti, which he dedicated to Urban VIII, and that in this same work he mentions the inventions of Vincenzo Vincenzi, specifically the wind gun and the portable fountain, but there is no solid evidence in the form of a reference in Castelli's book or anywhere else to the possible involvement of Vincenzi in the draining of these marshes. ${ }^{82}$ However, Vincenzi did participate in another large-scale land reclamation project that was being undertaken at the time in northern Italy on the plain of the River Po. In 1604 Pope Clement VIII issued a brief that opened the way for the Bonificazione Generale of the three provinces of Bologna, Ravenna and Ferrara. During the 16th century, far-reaching schemes had already been implemented here, which were particularly ambitious in the area of Ferraresa with the so-called "Bonifica del Gualtieri" initiated by Cornelio Bentivoglio in 1566 and on which the architect, engineer and hydrologist Giovan Battista Aleotti worked for several years. This was where Vincenzo Vincenzi would be engaged afterwards, when Cornelio's successor Enzo Bentivoglio, the brother of Cardinal Guido Bentivoglio, endeavoured from 1609 onwards to reclaim the area between the River Po and the River Tartaro, in the so-called "Bonifica del Zelo e Stienta," ${ }^{83}$ work that dragged on at great cost for several years. In his correspondence with Querini, Vincenzi indicates it was just after he had made the acquaintance of Cardinal Bentivoglio and his brother the Marquis Enzo that he received the summons of Cardinal Borja. ${ }^{84}$ Precisely because he was asked in this context to participate in

82 Castelli, Della misura (cit. note 40), pp. 17-18: “[...] come si vede per esperienza nell' Archibuso a vento, inventato a nostri tempi da M. Vincenzo Vincenti Urbinate, la quale condizione dell'aria di potere essere condensata si vede ancora nelle fontane portatili del medesimo M. Vincenzo, le quali Fontane schizzano in alto l'acqua a forza di aria compressa, la quale, mentre cerca ridursi alla sua naturale costituzione, nel dilatarsi, fa quella violenza $[\ldots] . "$

83 Franco Cazzola, "Bonifiche e investimenti fondiari," in Storia della Emilia Romagna, edited by Aldo Berselli (Bologna: Bologna University Press, 1977), pp. 209-228.

84 CorrerVe, Codice Cicogna, 2799, 156r, “[...] io havea ancora modi da restringerla, e questo 
the draining of the Gandía salt marsh, we can hypothesize that the contact between Vincenzi and the Bentivoglios derived from his involvement in the Ferraresa land reclamation scheme. In this sense, his experience in Italian marsh drainage projects could explain why Borja commissioned him to implement a similar scheme in Spain.

\section{The Gandía Salt Marsh}

When Vincenzi arrived in Gandía it was ruled by Carlos Francisco de Borja y Centelles, the 7th Duke of Gandía and the brother of Cardinal Gaspar de Borja. He also would have met the duke's son (and therefore the nephew of the cardinal), Francisco Diego Pascual de Borja y Centelles, who would inherit the dukedom in 1632 . Both were married to members of the Doria family of Genoa; Carlos Francisco to Artemisia Doria Caretto and Francisco Diego to Artemisia Doria Colonna. This rapprochement between the Borjas and the wealthy Doria family, which was known for its generous dowries, was crucial because the Duchy was in grave financial straits. ${ }^{85}$ It had been teetering on the edge of bankruptcy since the end of the 16th century, in a situation that was aggravated by the expulsion of the Moriscos in 1609. The Moriscos provided an estimable workforce that had sustained agricultural production on the ducal estates in Gandía, which were given over principally to the cultivation of sugar cane and the production of sugar, supplemented by the growing of other crops such as rice, fruit and vegetables. ${ }^{86}$ In 1610 the Duchy had its rents sequestered and the duke was elevated to the post of Viceroy of Sardinia, which by distancing him from his possessions was effectively a sentence of exile, from which he returned in 1618. Even though from 1611 onwards he sought to resettle agricultural workers on his lands in an attempt to alleviate the situation and an agreement was reached with the annuitants in 1621, the disaster was patent. The cardinal was aware of the problems, even directly so in some instances, as settlers, who included Genoans among their number, sent him letters complaining about the lack of land and the duke's non-compliance with the terms of their agreement. ${ }^{87}$

allhora si trataba col s. cardinale Bentivoglio e col Marchese Enzio suo fratello e le loro tenute nel ferrarese [...]."

85 Pizarro, Bisnieto (cit. note 67), pp. 107-135.

86 Santiago Laparra, Los Borja y los moriscos (Valencia: Institut Alfons el Magnànim, 1992).

87 Santiago Laparra, El ducado de Gandía en el siglo XVII, PhD thesis (Valencia: Universidad de Valencia, 1990), p. 66o. 
The dukes in this period were no longer continuously in residence at the ducal palace in Gandía. They had to attend to their royal court duties, such as that of High Steward to Queen Isabel of Bourbon, a title bestowed on the 7th Duke in 1630 . His poor health did not allow him to dedicate much time to this post, and he died in 1632 when he was apparently residing in Gandía. His son, Francisco Diego Pascual, divided his time between Valencia, Madrid and the ducal estates. In addition to the main palace in the town of Gandía, special importance was given at the time to two other palaces: the Real de Gandía in a village just a few kilometres from Gandía and the Alquería de don Alonso located at the foot of Bayrén Castle, between the present-day town centre and The Grao by the sea.

Dating back to the Middle Ages, the Palace of Real was a fortified edifice built along the lines of the palaces of the Crown of Aragón, with a square ground plan, a voussoired entrance gate, corner towers, large windows, and a central courtyard with stairs leading to the main rooms. ${ }^{88}$ At the time of Vincenzi's visit to Gandía, it also featured a wing that served as a sugar cane mill or trapig, for cutting and shredding sugarcane, boiling the juice and storing the end product, ready for transport and sale. ${ }^{89}$ Documents reveal that the palace also had a sizable pleasure garden, and that over the years enclosed balconies and galleries were added to afford views of the fields extending down to the sea.

Now practically in ruins, it is hard to envisage its past grandeur, yet what have indeed come down to us are descriptions of certain features that might have been added during the period in question. The garden was dominated by a large pond where, at the end of the 19th century, there were still three large statues made from stalactites extracted from caves located in the nearby valley of Marchuquera. These statues, whose unhewn lower parts were submerged in the water, depicted a medieval warrior, a giant bearing a basket of fruit on its head, and an eagle with another basket in its talons. ${ }^{90}$ At the end of the 19th century the palace was dismantled and sold; its new owners, the Marquises of Quirós, had parts of the statues removed to the local museum for

88 Description in Luis Arciniega, La memòria del ducat de Gandía i els seus títols annexos. Redactada per Basilio Sebastián de Castellanos per al duc d'Osuna (1851-1852) (Gandía: CEIC, 2001), p. 163 and p. 210.

89 Josep. A. Gisbert, "Arquitectura, arqueología i empremta material del sucre a la Safor: trapigs i enginys del duc," in Sucre i Borja. La canyamel dels ducs, edited by Josep A. Gisbert (Gandía: Generalitat Valenciana 200o), pp. 109-168.

$90 \quad$ Arciniega, La memoria (cit. note 88), p. 210. 
their conservation. ${ }^{91}$ At the beginning of the 2oth century it was still possible to see a fragment of the warrior's helmet, which had been initially placed in the vivero or nursery garden of the palace in Gandía ${ }^{92}$ and then on the patio, and the giant sculpted in dark, nearly black, stone, whose lower section bears a cartouche, its arms and the basket on its head now missing. We do not know when this pond was built, but the 17th-century style of the statues with which it was embellished could tally with the time when Vincenzi an expert in landscape gardening and fountains - was in Gandía. Other later works were carried out in 1689-169o, corresponding to the moment when the Palace of Real was renovated, with the addition of marble elements such as façades, window frames, new fountains, and the aforementioned gallery in which the renowned sculptor Raimundo Capuz participated..$^{93}$ Also belonging to this period are the sculptures of the Caesars, which were commissioned from Gerónimo Carmañoli in Rome through the mediation of Canon Vicente Vitoria; ${ }^{94}$ in $1883-1885$ the statues were sent from Gandía to the Alameda de Osuna (Madrid), where they are still kept today. ${ }^{95}$

The other important building in the vicinity of the salt marsh on which Vincenzi worked is the well-known Alquería de don Alonso, located on the outskirts of Gandía. It was purchased by Don Alonso de Borja y Castro, the youngest son of Francisco de Borja, around 1590. He ordered work to be started on the building to transform it into a manor house, but his plans were curtailed by his death in 1593. After a series of lawsuits arising from testamentary issues, its ownership reverted to the Borja family around 160o, when presumably the

91 Federico Cervós and Juan María Sola, El palacio ducal de Gandía (Barcelona: J. Tomás, 1904), p. 249. "Dos bustos de mármol negro procedentes del palacio de los duques en el Real, regalo del señor Marqués de González."

92 Antonio León, Guía del Palacio Ducal y de otros insignes recuerdos de los Borja en la ciudad de Gandía (Valencia: Tipografía Moderna, 1926), p. 103. "En este lugar, (Vivero) se han colocado algunas figuras de piedra procedentes del palacio del Real y debidas a la generosidad del señor Marqués de González de Quirós [...]."

93 Arciniega, La memoria (cit. note 88), pp. 113-115, and AHN, Osuna, C.803, D. 3.

94 Archivo Histórico Nacional (AHN), Nobleza, Osuna, Cт, 393, D.9, Roma, 26 de junio de 1689, "Haviendo en execucion de lo que se sirvió ve de mandarme hecho empezar como le tengo avisado las ninfas de vulto de piedra que desea para adornar un patio de ese palacio, ha llegado ha hablarme un escultor y maestro de obra de tal genero llamado Geronimo Carmañoli natural de esta ciudad los días pasados enseñándome una carta del canónigo Vitoria en la que le dize que vE gusta le haga unas cabezas de mármol de emperadores antiguos [...]."

95 AHN, Nobleza, Osuna, CT, 393, D.19, "Cartas de los años 1883-85, Remisión de las estatuas que hay en el palacio de Gandía para la Huerta de la Alameda." 
renovation of the building was resumed and completed. ${ }^{96}$ This property as well was affected by problems arising from the expulsion of the Moriscos, and in 1611 it was warned that, despite "es nueva y de buen edificio, por no habitarse, amenaza ruyna." ${ }^{97}$ However, in this case it was perhaps more a case of financial ruin than physical ruin, brought about by the decline in agricultural production. Recently this building has been renovated and converted into a visitors' centre for the surrounding salt marsh. According to contemporary reports, the dukes converted the fortress into a pleasure palace in which to pass the summer months because it offered a cool spot in the countryside..$^{98}$ They embellished it with gardens, and above all enhanced the large pond, which was in reality a spring forming part of the Gandía salt marsh. Inherited by María Ponce de León, Dowager Duchess of Gandía and widow of the Ixth duke Francisco de Borja, this palace was visited by Empress Margaret of Austria (1651-1673) in May $1666,{ }^{99}$ when she was passing through Gandía before embarking for Germany on the way to her wedding with Emperor Leopold I (1640-1705). She was wined and dined for several days, and enjoyed boating on the pond, accompanied by musicians who enlivened these excursions.

The Gandía salt marsh forms the southern tip of a larger marshy area: the Safor salt marsh, which stretches over nearly 20 kilometres of coastline between the mouths of the River Vaca or Xeraco (Tavernes de la Valldigna) and the River San Nicolau (Gandía), also comprising the municipalities of Xeresa and Xeraco. Located at the foot of Mount Mondúber, very close to the sea, these wetlands are fed by groundwater surfacing in aquifers called ullals, like the natural springs visible in the vicinity of the Alquería, such as that of Estany del Duc. The drainage works in this area date back to the Middle Ages, when in the 13th century, soon after the Christian conquest, two large irrigation canals were built, those of Rei and Ahuir, which were then supplemented by two more in the following century. ${ }^{100}$ Following the completion of these projects,

96 Jose María Cruselles, “L'Alqueria del Duc, noticies d'arxiu," Espai Obert, 1996, 3:75-78.

97 Laparra, El ducado (cit. note 87), p. 313. "It is new and well built, but as it is uninhabited, it runs the risk of falling into ruins."

98 Arciniega, La memoria (cit. note 88), p. 209.

99 Roque Chabás, "La visita de la emperatriz Margarita de Austria a Gandía en 1666," El Archivo, 1886/1887, 1:107-110 and AHN, Osuna, C. 745, D. 1, Cuentas de lo que gastó por la estancia de la Emperatriz de Austria, la infanta Margarita de España, hija de Felipe IV y Mujer de Leopoldo I en Gandía a 14 de mayo de 1666.

100 Josep Torró, "Tierras ganadas. Aterrazamiento de pendientes y desecación de marjales en la colonización cristiana del territorio valenciano," in Por una arqueología agraria, edited by Helena Kirchner (Oxford: BAR International Series 2062, 2010), pp. 157-172. 
a land reclamation process was initiated to convert the area into arable land for new settlers who then began to drain and plough it. However these largescale works took years to complete. At the beginning of the 16th century, at the time of the Duchess María Enríquez, fresh impetus was given to the drainage programme, with the aim of increasing the cultivation of sugarcane, which had come to form an important part of the economy. Since the extent of the area was vast and the need for arable land enormous, the land reclamation scheme was pursued over the following centuries.

Cardinal Borja's financial concerns might have coincided with this especially complicated economic period for Gandía, when as a consequence of the expulsion of the Moriscos the cultivation of sugar cane was gradually abandoned and replaced by that of rice. The marshlands were particularly well suited to rice cultivation, which required huge amounts of water. So the draining of the land was perhaps undertaken with an eye to satisfying the demands of the new settlers and, in the process making the area more salubrious for its inhabitants. We know from the settlement charters that each settler received 20 hanegadas of irrigated land, 20 of dry land, olive groves equivalent to a day's labour, and as much marshland as he could cultivate. ${ }^{101}$ Therefore, this was a way of both appeasing the settlers and increasing the amount of arable land available, while making it a healthier place to live.

As already mentioned, however, we do not have any precise information about Vincenzi's involvement, which we assume can be dated to sometime between 1630 and 1635 , or at least from 1635 onwards. Meanwhile, Cardinal Gaspar de Borja was still residing in Rome, and did not return to Spain until 25 April 1635, when we know that Vincenzi was certainly in Gandía. What we cannot be so sure about is whether Vincenzi arrived as planned at the beginning of October 1630 or afterwards, and how long he stayed. After this date, he was not recorded as being either in Spain or Italy, thereby making it difficult to analyse the completion of his work.

What we do know is that the efforts to drain the marsh must have been insufficient because the problem still persisted, insofar as in the mid-18th century Mosén Casimiro Medina of Xàtiva, another great architect, mathematician and hydrologist, was commissioned to level the Gandía, Xeresa and Xeraco salt marshes. ${ }^{102}$ He submitted a new report detailing the work required to drain the marshes and thus make the land available for agricultural use, but we know

\footnotetext{
101 Laparra, El ducado (cit. note 87), p. 183.

102 AHN, Nobleza, Osuna, C. 547, D. 68-71 “[...] En la ciudad de Gandía a dos de febrero de mil setecientos quarenta y un años Mosen Casimiro Medina vecino de la ciudad de San Felipe arquitecto, Ydometra y demás ciencias matemáticas, profesor dixo: como habiendo
} 


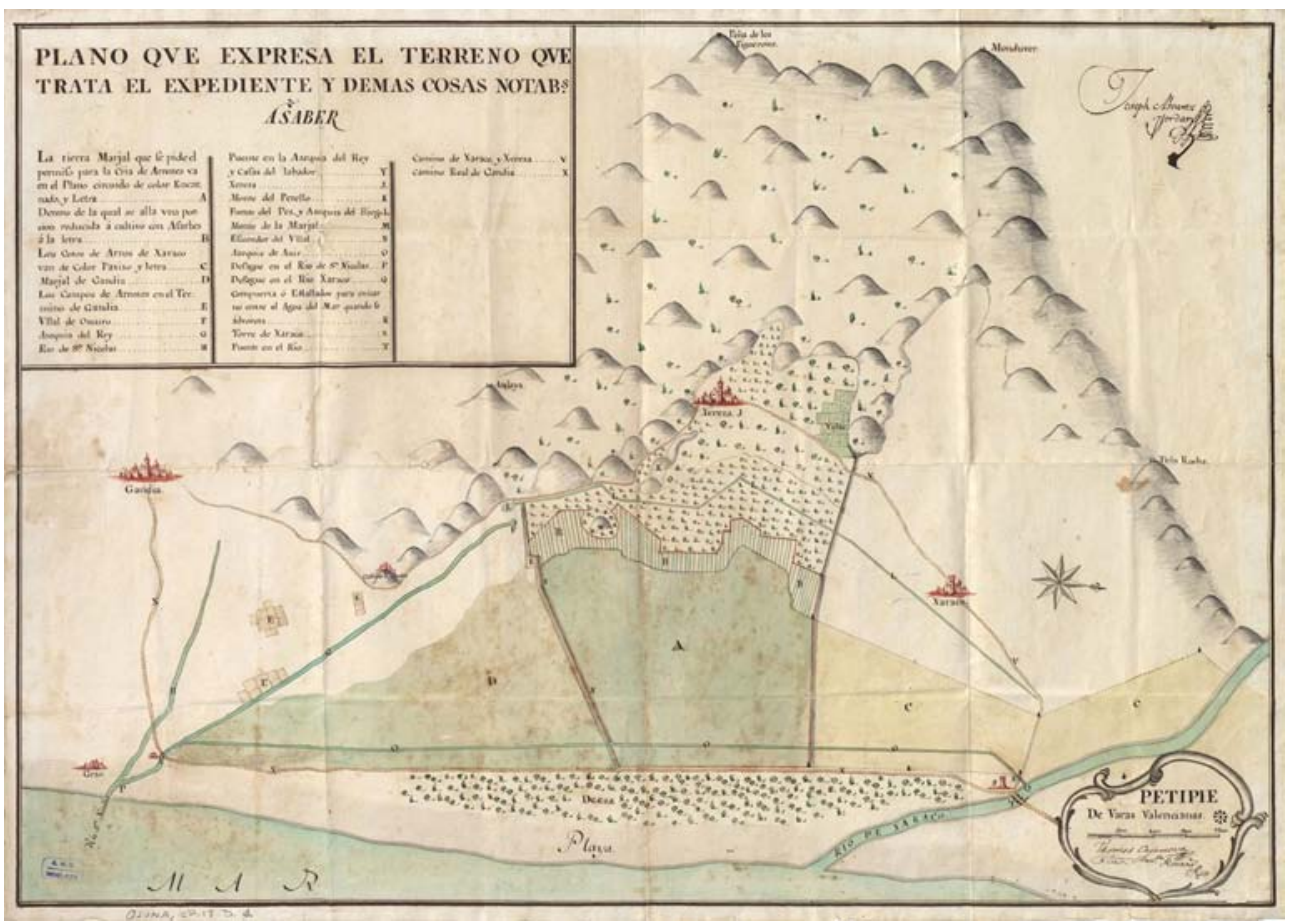

FIGURE 6 Casimiro Medina, Map of the salt marsh of Gandía, 1748

ARCHIVO HISTÓRICO NACIONAL, MAPAS Y PLANOS, CP. 18. D.1.

this work was never carried out. Nonetheless, we still have a map ${ }^{103}$ of the area between the River San Nicolás and the irrigation canal of Rey, where a fair amount of work had already been done and paddy fields had begun to appear, while vestiges of the area still remained untouched. Drawn by Casimiro Medina in 1748 , this map shows exactly where Vincenzi must have laboured. (Fig. 6)

Whatever work Vincenzi carried out in Gandía, his presence in Spain allows us to complete the profile of an elusive character, whom we find designing fountains and gardens, channelling waters, and inventing artefacts which astonished his contemporaries and became collector's items. This reconstruction

reconocido las amarjales de dicha ciudad de Gandía y lugares de Xeresa y Xaraco, su situación, diferencias entre ellas y los ríos de Xaraco, San Nicolás y orilla del mar, nivelando con toda exactitud los declirios de las expresadas amarjales, como también haver oído, o informándose de los naturales y practicos de ellas de los varios estados de ela mar y expresados ríos es de dictamen deverse evacuar las aguas de las amarjales incultas y beneficiar las cultas, según y conforme se expresarán en este proiecto [...]."

103 AHN, Nobleza, Mapas y Planos, CP. 18, D.1. 
of his biography allows us to paint the picture of a unique type of artificer half artist, half man of science - and his dazzling client portfolio, and thus demonstrates, at least to our mind, that Vincenzo Vincenzi of Urbin and Vicentio Vincensi, Roman geometer and engineer to Cardinal Borja, were one and the same person. 